\title{
EFFECT OF GAS ATMOSPHERE ON THE NON-METALLIC INCLUSIONS IN LASER-WELDED TRIP STEEL WITH Al AND Si ADDITIONS
}

\author{
VPLIV PLINSKE ATMOSFERE NA NEKOVINSKE VKLJUČKE V \\ LASERSKO VARJENEM TRIP JEKLU Z DODATKOM Al IN Si
}

\author{
Adam Grajcar ${ }^{1}$, Maciej Różański², Małgorzata Kamińska ${ }^{3}$, \\ Barbara Grzegorczyk ${ }^{1}$ \\ ${ }^{1}$ Silesian University of Technology, Institute of Engineering Materials and Biomaterials, Konarskiego Street $18 \mathrm{a}$, 44100 Gliwice, Poland \\ 2Institute of Welding, B1. Czesława Street 16-18, 44100 Gliwice, Poland \\ ${ }^{3}$ Institute of Non Ferrous Metals, Sowinskiego Street 5, 44100 Gliwice, Poland \\ adam.grajcar@polsl.pl
}

Prejem rokopisa - received: 2015-08-12; sprejem za objavo - accepted for publication: 2015-11-04

doi:10.17222/mit.2015.253

\begin{abstract}
The present study aims to characterize the weldability of a multiphase, automotive steel containing $\mathrm{Al}$ and $\mathrm{Si}$ additions from the point of view of its tendency to form non-metallic inclusions. Laser welding tests of 2-mm-thick sheets were performed using the keyhole-welding mode and a solid-state laser. The tests were carried out in air and with the use of an argon atmosphere. The distribution, type and chemical composition of the non-metallic inclusions formed in the base metal and fusion zones were analysed. The effect of applying the protective gas on the type and amount of non-metallic inclusions was determined using light and scanning electron microscopy. The chemical composition of the identified particles was assessed using the EDS method. It was found that a protective gas has a beneficial effect on reducing the non-metallic inclusions, but only to a limited extent. The boundary between the complex oxides and the pure aluminium oxides was determined to be $2-3 \mu \mathrm{m}$.
\end{abstract}

Keywords: TRIP steel, laser welding, non-metallic inclusions, protective gas, Ar atmosphere, oxidation

Namen te študije je opredeliti varivost s stališča tvorbe nekovinskih vključkov v večfaznem jeklu, ki vsebuje Al in Si, za avtomobilsko industrijo. Izvedeni so bili varilni preizkusi z laserjem na $2 \mathrm{~mm}$ debelih pločevinah z V zarezo. Preizkusi so bili izvedeni na zraku in v zaščitni atmosferi argona. Analizirana je bila razporeditev, vrsta in kemijska sestava nekovinskih vključkov v osnovnem materialu in v coni zlivanja. Vpliv uporabe zaščitnega plina na vrsto in količino nekovinskih vključkov je bil določen s pomočjo svetlobne in vrstične elektronske mikroskopije. Kemijska sestava najdenih delcev je bila ugotovljena z metodo EDS. Ugotovljeno je bilo, da ima zaščitni plin ugoden vpliv na zmanjšanje nekovinskih vključkov le v omejenem obsegu. Meja med kompleksnimi oksidi in čistimi oksidi aluminija je bila določena kot 2-3 $\mu$ m.

Ključne besede: TRIP jeklo, lasersko varjenje, nekovinski vključki, zaščitni plin, atmosfera Ar, oksidacija

\section{INTRODUCTION}

Multiphase steels with a transformation-induced plasticity (TRIP) effect belong to the advanced highstrength steels (AHSS) used in the modern automotive industry. The beneficial balance between strength and ductility requires increased contents of $\mathrm{Mn}, \mathrm{Al}$ and $\mathrm{Si}$. Their total content in TRIP steels can reach $4 \% .{ }^{1-3}$ Medium-Mn and high-Mn alloys require an even higher concentration of alloying elements. ${ }^{4-8}$ Whereas a lot of efforts focus on the relationships between hot-working, heat-treatment, microstructure and mechanical properties, the weldability of AHSS has not received much attention so far.

M. S. Weglowski et al. ${ }^{9}$ reported that the maximum hardness in the fusion zone of $0.07 \mathrm{C}-1 \mathrm{Mn}-0.4 \mathrm{Cr}$ dual-phase steel (which belongs to the $1^{\text {st }}$ generation of AHSS) reaches $340 \mathrm{HV}$. The hardness increases to approximately $430 \mathrm{HV}$ with increasing carbon and manganese contents in the $0.13 \mathrm{C}-1.3 \mathrm{Mn}-0.2 \mathrm{Cr}-0.2 \mathrm{Cu}$ steel. ${ }^{10}$ Another problem in high-strength, multiphase steels is the heat-affected zone (HAZ) softening because of the tempering of the pre-existing martensite. Since the AHSS contain a high alloying content their weldability should also be affected by the presence of non-metallic inclusions. Different sulphide and oxide particles have been identified by M. Amirthalingam et al. ${ }^{11}$ and A. Grajcar et al. ${ }^{12}$ in different types of TRIP steels containing $\mathrm{Mn}, \mathrm{Si}$ and $\mathrm{Al}$ additions. It is well known that brittle oxides and ductile manganese sulphides affect the fatigue endurance limit, the fatigue-crack propagation rate, the fracture toughness, the anisotropy of the tensile properties with respect to the rolling direction and the weld quality, too. ${ }^{13,14}$

Recently, A. Grajcar et al. ${ }^{12}$ analysed various types of non-metallic inclusions in laser-welded Fe-1.5Mn0.9Si-0.4Al TRIP steel. Numerous oxide-type particles have been revealed in the fusion zone formed under air conditions. Therefore, the aim of the present work is to investigate the effect of a protective gas on the quantity, type and chemical composition of non-metallic inclusions in Si- and Al-alloyed TRIP steel. 


\section{EXPERIMENTAL PART}

The work addresses the laser welding of thermo-mechanically processed, 2-mm-thick, TRIP steel sheets with the following chemical composition: $0.24 \% \mathrm{C}$, $1.55 \% \mathrm{Mn}, 0.87 \% \mathrm{Si}, 0.4 \% \mathrm{Al}, 0.03 \% \mathrm{Nb}, 0.023 \% \mathrm{Ti}$, $0.004 \% \mathrm{~S}, 0.01 \% \mathrm{P}$ and $0.0028 \% \mathrm{~N}$. Rare-earth elements (REE) such as mischmetal ( $\sim 50 \% \mathrm{Ce}, \sim 20 \% \mathrm{La}$, $\sim 20 \% \mathrm{Nd}$ ) were added to modify the chemical composition and the shape of the non-metallic inclusions. The $25-\mathrm{kg}$, vacuum-melted ingot was cast using a protective atmosphere of argon. The $\mathrm{Si}+\mathrm{Al}$ addition is required in TRIP steels to prevent carbide precipitation because $\mathrm{C}$ is needed to enrich the retained austenite. $.^{1,2,11} \mathrm{The} \mathrm{Nb}+\mathrm{Ti}$ micro-additions are added to increase the strength level as a result of the precipitation strengthening and grain refinement. These phenomena are especially useful for thermo-mechanically processed steels. ${ }^{15,16}$

The initial hot-working included the hot forging and rough rolling of the ingot to a thickness of $5 \mathrm{~mm}$. The fundamental thermo-mechanical rolling consisted of 3 passes with a finishing rolling temperature of $850{ }^{\circ} \mathrm{C}$. The major step of the controlled cooling following the hot rolling was isothermal holding of the sheets at a temperature of $350{ }^{\circ} \mathrm{C}$ within $600 \mathrm{~s}$. The final thickness of the sheets was $2 \mathrm{~mm}$.

Laser welding generally includes two major modes: keyhole welding and conductive welding. ${ }^{17}$ The conductive welding utilizes the natural thermal conduction into the material. The welds obtained in this welding mode have good quality and do not contain pores and spalls. However, the keyhole welding is more efficient. Because of this the present tests were carried out using keyhole welding. In this treatment mode the power density is much higher compared to the conductive welding and the fusion depth is much higher compared to the diameter of the liquid pool. The welding tests were performed using a solid-state laser integrated with a robotized laser-treatment system. The welding station is equipped with the TruDisk 12002 solid-state laser type Yb:YAG characterized by a maximum power of $12 \mathrm{~kW}$. The heat input value of $0.048 \mathrm{~kJ} / \mathrm{mm}$ was applied. The welding tests were performed using an Ar atmosphere. To assess the effect of the protective atmosphere, tests under air conditions were performed too.

The distribution, type and chemical composition of the non-metallic inclusions formed in the base metal (BM) and fusion zone (FZ) of both types of samples (using Ar gas and without any protective gas) were compared. Samples for light microscopy (LM) and scanning electron microscopy (SEM) were prepared. The chemical composition of the non-metallic inclusions was assessed using EDS point analyses. The distribution of the particular alloying elements was revealed using mapping. The quantitative measurements of the chemical composition for the identified inclusions were carried out using a JCXA 8230 X-ray micro-analyser with an accelerating voltage of $15 \mathrm{kV}$. The microstructures of the $\mathrm{BM}$, the heat-affected zone (HAZ) and the FZ were revealed using the SUPRA 25 SEM at an accelerating voltage of $20 \mathrm{kV}$ after nital etching.

\section{RESULTS AND DISCUSSION \\ 3.1 Distribution of non-metallic inclusions}

The use of different gas atmospheres influences the quantity of non-metallic inclusions. The distributions of non-metallic inclusions formed in the fusion zones under the conditions of an air atmosphere and Ar protective gas are compared in Figure 1. The intense oxidation takes place when the laser welding was conducted without any protective gas. As a result numerous particles of different sizes can be observed in the fusion zone. The clear boundary near the fusion line is easily visible in Figure $\mathbf{2}$ for both the air- and Ar-treated samples. The amount of particles in the heat-affected zone is a few times lower when compared to the fusion zones.

The size of the non-metallic inclusions is similar when the protective gas was applied. The quantity of particles is lower compared to the laser treatment without any protective atmosphere. However, the amount of non-metallic inclusions for Ar-protected samples is higher than would be expected. This means that the Ar atmosphere has a limited efficiency in the reduction of harmful, non-metallic inclusions formed in the fusion zone. The explanation is the essence of the keyholewelding technique. The high-density power in the region of the laser beam's exposure creates a gas-dynamic
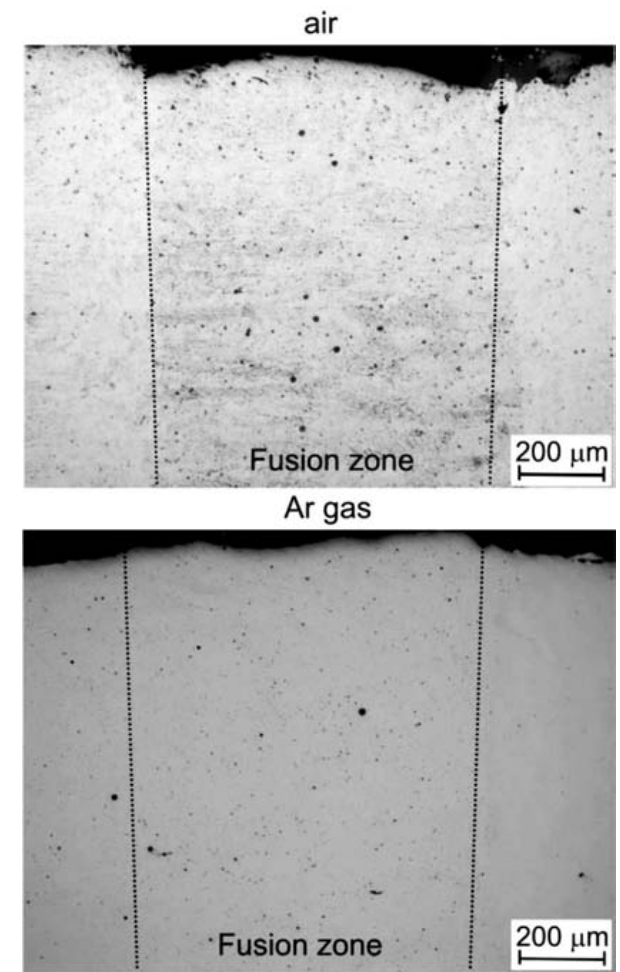

Figure 1: Distribution of non-metallic inclusions in the fusion zones formed under conditions of air atmosphere and Ar protective gas Slika 1: Razporeditev nekovinskih vključkov v področju zlivanja, nastalih na zraku in v zaščitni atmosferi Ar 



Figure 2: Distribution of non-metallic inclusions near the fusion line in the fusion zones and heat-affected zones formed under conditions of air atmosphere and Ar protective gas

Slika 2: Razporeditev nekovinskih vključkov blizu linije področja zlivanja in toplotno vplivane cone, nastalih na zraku in v zaščitni atmosferi $\mathrm{Ar}$

channel, i.e., a deep and narrow capillary filled with gases and metal steams. ${ }^{17,18}$ These turbulent gases partially break the protective atmosphere of the argon. That is why the amount of non-metallic inclusions for laser welding tests with the use of Ar gas is higher than expected.

\subsection{Microstructure of the steel}

The microstructure of the base metal consists of polygonal ferrite (F) grains elongated along the hot-rolling direction, bainite and retained austenite (Figure 3). Retained austenite (RA) is the most favourable structural constituent of TRIP steels due to its beneficial effect on increasing the steel's plasticity. This phase is usually found as small, blocky, granules along ferrite grain boundaries or between bainitic ferrite laths. Hence, a large fraction of the microstructure constitutes bainiteaustenite (BA) constituents.

The rapid cooling rate typical for laser welding influences the microstructure of the fusion zone. Typical SEM microstructures of the fusion zone are shown in Figure 4. Both microstructures are characterized by the presence of martensite laths. Due to the chemical contrast typical for observations using back-scattered electrons (BSE) white interlath retained austenite (RA) can also be observed. The amount of non-metallic inclusions

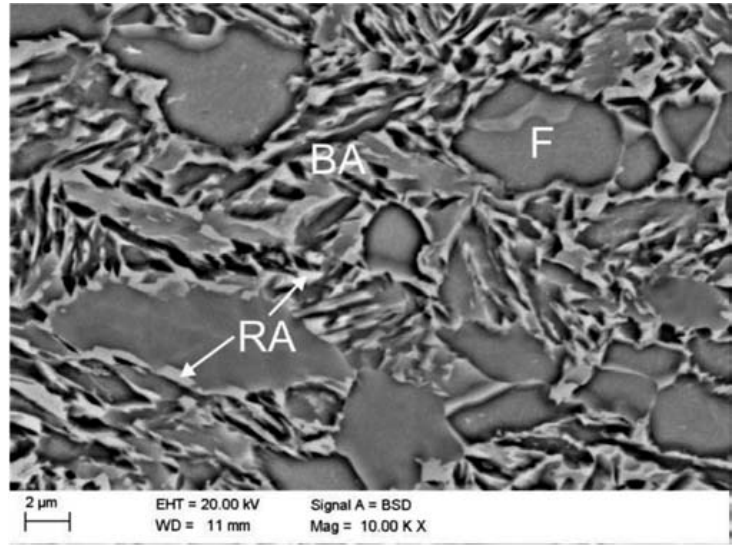

Figure 3: SEM microstructure of the base metal consisting of ferrite (F), bainite-austenite constituents (BA) and retained austenite (RA) Slika 3: SEM-posnetek mikrostrukture osnovnega materiala, ki jo sestavljajo ferit (F), bainit-avstenit (BA) in zaostali avstenit (RA)

is slightly smaller for the samples welded using the argon gas. Moreover, a lot of sub-micron-sized particles are formed in this steel.

\subsection{Non-metallic inclusions}

The amount of non-metallic inclusions in the base metal is very small (Figures $\mathbf{1}$ and 2). It is related to the high metallurgical cleanliness of the laboratory-melted steel and the use of rare-earth elements. A result of the mischmetal addition is a partial or total substitution of
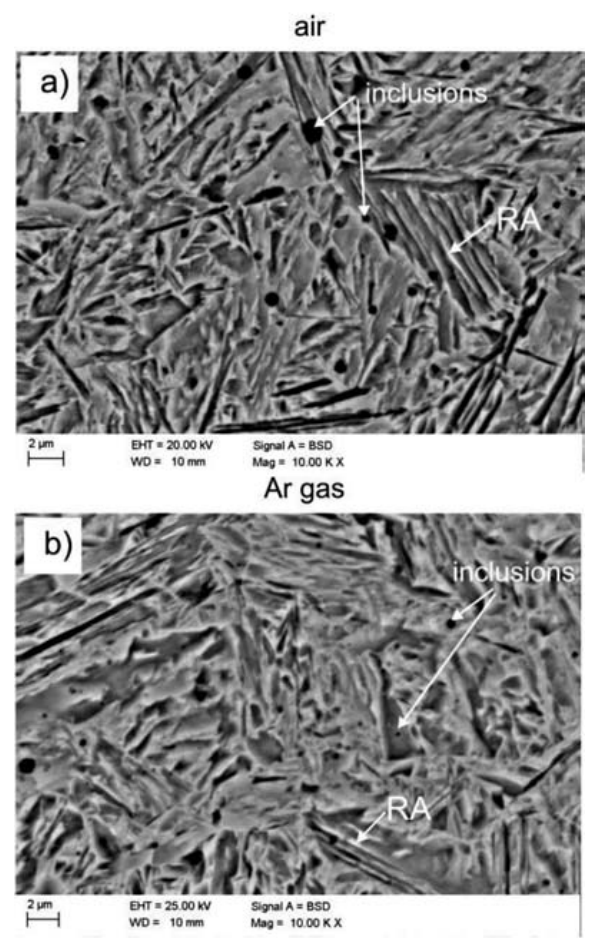

Figure 4: Martensite laths and globular non-metallic inclusions formed in the fusion zones under conditions of: a) air atmosphere and b) Ar protective gas

Slika 4: Martenzitne late in globularni nekovinski vključki, nastali v coni zlivanja: a) na zraku in b) $\mathrm{v}$ zaščitni atmosferi Ar 



c)

\begin{tabular}{c|c|c} 
point 1 & wt. \% & at. \% \\
\hline $\mathrm{O}$ & 8.2 & 36.4 \\
\hline $\mathrm{S}$ & 8.9 & 19.6 \\
\hline $\mathrm{Fe}$ & 3.0 & 3.8 \\
\hline $\mathrm{La}$ & 7.6 & 3.9 \\
\hline $\mathrm{Ce}$ & 72.3 & 36.4
\end{tabular}

Figure 5: Complex oxysulphide containing La and Ce: a) formed in the base metal, b) spectrum of the inclusion and c) its chemical composition determined using EDS

Slika 5: Sestavljeni oksisulfid, ki vsebuje La in Ce: a) nastal v osnovnem material, b) spekter vključka in c) njegova kemijska sestava, določena s pomočjo EDS

Mn in sulphide inclusions and $\mathrm{Al}$ in oxide inclusions by the REE. These elements have a higher chemical affinity for sulphur and oxygen compared to $\mathrm{Mn}$ and $\mathrm{Al}$. The example of such a particle is shown in Figure 5. In this case $\mathrm{Ce}$ and $\mathrm{La}$ totally replaced $\mathrm{Mn}$ and $\mathrm{Al}$, forming a globular oxysulphide. Such particles are hardly deformed during hot rolling and reduce the anisotropy of the mechanical properties of flat products. ${ }^{4,15}$ The mapping of the globular inclusions indicates that $\mathrm{Ce}$ and $\mathrm{La}$ as well as $\mathrm{S}$ and $\mathrm{O}$ are distributed uniformly within the particle (Figure 6).

Figure 7 presents typical non-metallic inclusions formed in the fusion zone of the sample laser-welded in

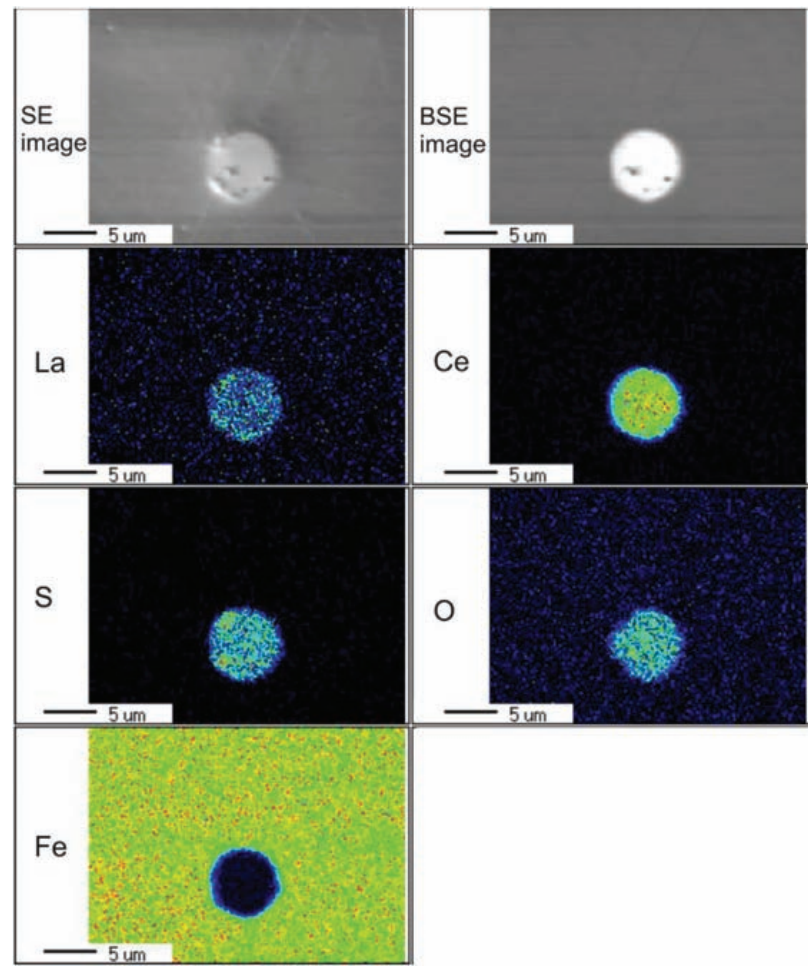

Figure 6: Elemental mapping of the particle from Figure 5 Slika 6: Razporeditev elementov v delcu prikazanem na Sliki 5



b) point1



c) point 2

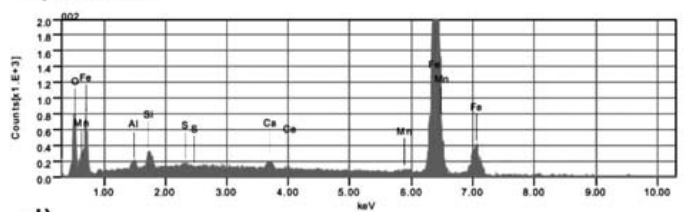

d)

\begin{tabular}{c|c|c} 
point 1 & wt. \% & at. \% \\
\hline $\mathrm{O}$ & 42.7 & 62.7 \\
\hline $\mathrm{Al}$ & 11.0 & 9.6 \\
\hline $\mathrm{Si}$ & 19.4 & 16.2 \\
\hline $\mathrm{Ti}$ & 0.8 & 0.4 \\
\hline $\mathrm{Mn}$ & 26.1 & 11.1
\end{tabular}

Figure 7: Complex oxides of various size formed in the fusion zone of the sample welded in the air atmosphere: a), b) spectrum of the particle from point 1, c) spectrum of the particle from point 2 and d) the chemical composition of the large particle (point 1) determined using EDS

Slika 7: Sestavljeni oksidi različnih velikosti: a) nastali v coni zlivanja vzorca zvarjenega na zraku, b) spekter delca v točki 1, c) spekter delca $\mathrm{v}$ točki 2 in d) kemijska sestava velikega delca (točka 1), določena s pomočjo EDS 



Figure 8: Elemental mapping of the particles from Figure 7 Slika 8: Razporeditev elementov v delcih, prikazanih na Sliki 7

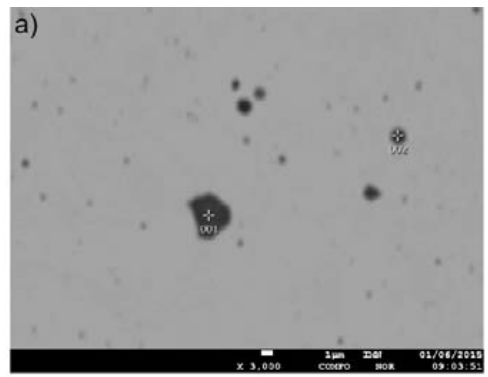

b) point 1

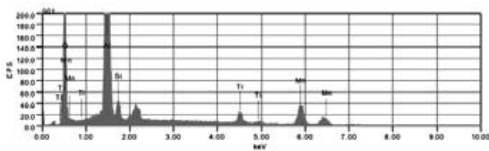

c)

\begin{tabular}{c|c|c} 
point 1 & wt. \% & at. \% \\
\hline $\mathrm{O}$ & 42.0 & 57.7 \\
\hline $\mathrm{Al}$ & 44.3 & 36.1 \\
\hline $\mathrm{Si}$ & 1.5 & 1.2 \\
\hline $\mathrm{Ti}$ & 2.7 & 1.2 \\
\hline $\mathrm{Mn}$ & 9.5 & 3.8
\end{tabular}

d) point 2

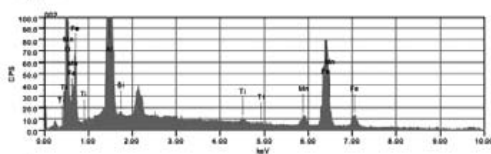

e)

\begin{tabular}{c|c|c} 
point 2 & wt. \% & at. \% \\
\hline $\mathrm{O}$ & 31.1 & 49.4 \\
\hline $\mathrm{Al}$ & 39.0 & 36.8 \\
\hline $\mathrm{Si}$ & 0.2 & 0.1 \\
\hline $\mathrm{Ti}$ & 0.6 & 0.3 \\
\hline $\mathrm{Mn}$ & 2.2 & 1.0 \\
\hline $\mathrm{Fe}$ & 26.9 & 12.3
\end{tabular}

Figure 9: Complex oxides of various sizes formed in the fusion zone of the sample: a) welded in the Ar atmosphere, b), d) spectra of the particles from points 1 and 2, c) the chemical composition of the particles from point 1 and e) point 2 determined using EDS

Slika 9: Sestavljeni oksidi različnih velikosti nastalih v coni zlivanja: a) vzorca zvarjenega v atmosferi Ar, b), d) spekter delcev iz točke 1 in 2 , c) kemijska sestava delcev iz točke 1 in e) točke 2 , določenih s pomočjo EDS the air atmosphere. There are a few large inclusions with a size ranging from approximately $3 \mu \mathrm{m}$ to $7 \mu \mathrm{m}$ and numerous small particles smaller than $1 \mu \mathrm{m}$. All the inclusions have a globular shape. EDS analyses of the large particles indicate that these are complex oxides containing Al, Mn and Si (Figures 7b to 7d). It indicates that there is a strong oxidation of the alloying elements in the air atmosphere. Elemental mapping indicates that there is no sulphur in the inclusions. Moreover, it should be noted that $\mathrm{Mn}$ and $\mathrm{Si}$ are located only at the largest inclusions, whereas the smaller ones are pure aluminium oxides (Figure 8).

The use of a protective atmosphere of argon causes a decrease in the amount of non-metallic inclusions. It is especially true for large particles, the quantity of which is much smaller (Figure 9a). As previously, the spectral lines in Figures 9b and 9d do not contain sulphur peaks. The intense evaporation during the keyhole welding results in the partial oxidation of the same alloying elements, like for the samples welded in the air atmosphere. Hence, many oxides can be identified in Figure 9. The analysis of the chemical composition indicates that the concentrations of $\mathrm{Mn}$ and Si decrease with a decrease in the particle diameter (Figures 9c and 9e). The presence of $\mathrm{Fe}$ in the spectrum of the smaller particle (point 2 in Figure 9) is caused by a similar diameter of the inclusion and a beam diameter. The occurrence of $\mathrm{Mn}$ and $\mathrm{Si}$ only in the largest inclusions is confirmed by Figure 10, where these elements are located in the largest particle of a diameter of approximately $4 \mu \mathrm{m}$. Some content of titanium was also revealed.

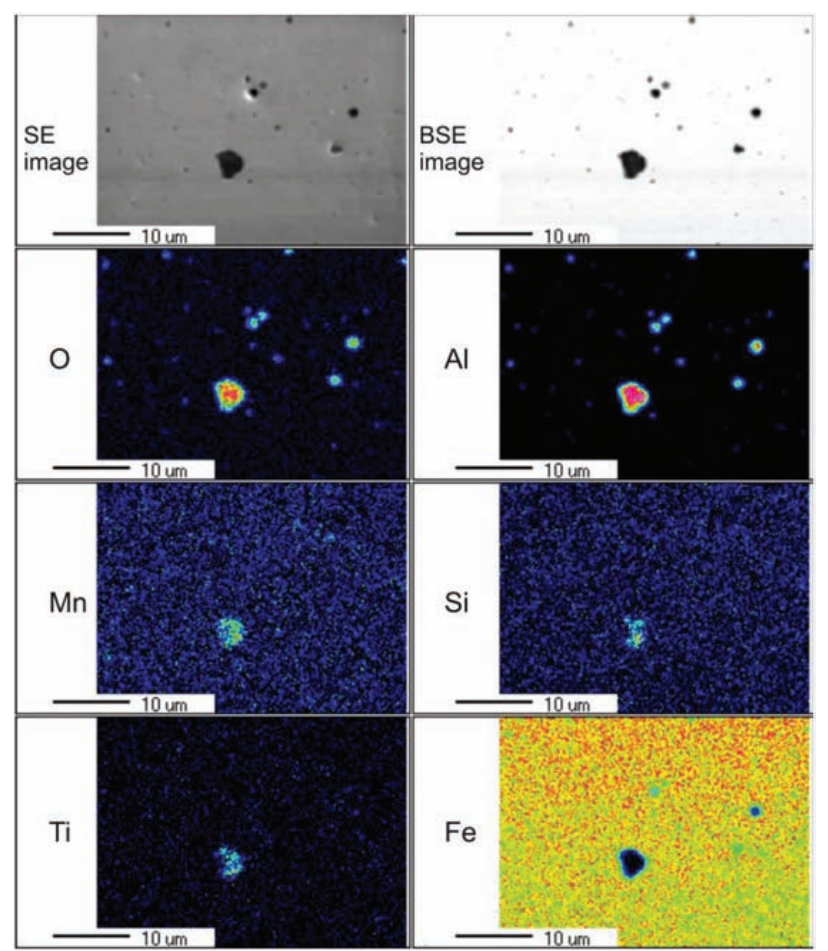

Figure 10: Elemental mapping of the particles from Figure 9 Slika 10: Razporeditev elementov v delcih, prikazanih na Sliki 9 


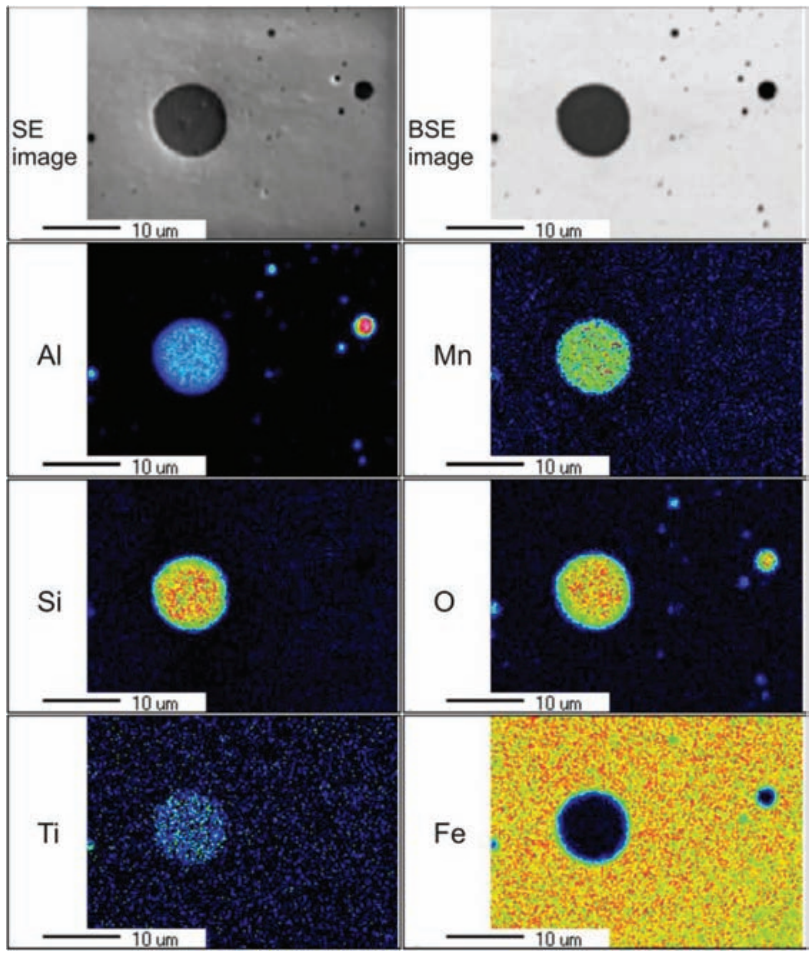

Figure 11: Elemental mapping of the complex oxides formed in the fusion zone of the sample welded in the Ar atmosphere

Slika11: Razporeditev elementov v sestavljenih oksidih, nastalih v coni zlivanja, vzorca zvarjenega v atmosferi Ar

$\mathrm{Ti}, \mathrm{Al}, \mathrm{Si}$ and $\mathrm{Mn}$ are also located in the largest inclusion in Figure 11. However, the amount of such large inclusions is reduced compared to the samples welded in the air atmosphere. The region around such large inclusions is usually free of any other particles. The limit between $\mathrm{Mn}$ - and Si-containing large inclusions and small pure aluminium oxides can be assessed as $2-3 \mu \mathrm{m}$.

\section{CONCLUSIONS}

The effect of the use of an Ar atmosphere during laser welding in the keyhole-welding mode was assessed for the Al-Si-bearing TRIP steel. It was found that the intense evaporation of gases and metal steams partially destroys the protective atmosphere of the argon. As a result, some oxidation of the weld pool takes place. The amount of non-metallic inclusions in the fusion zone of the samples welded using $\mathrm{Ar}$ is smaller compared to the samples treated without a protective gas. It concerns especially the large inclusions with a diameter between $3 \mu \mathrm{m}$ and $7 \mu \mathrm{m}$. The Ar atmosphere has no effect on the chemical composition of the formed particles. In both cases globular oxides of various sizes are formed in the fusion zone. The particles with a diameter ranging from $37 \mu \mathrm{m}$ to $7 \mu \mathrm{m}$ constitute the complex inclusions containing $\mathrm{Al}, \mathrm{Si}$ and $\mathrm{Mn}$ (sometimes also Ti). The numerous particles smaller than $2-3 \mu \mathrm{m}$ are pure aluminium oxides.

\section{Acknowledgment}

This work was financially supported with statutory funds of Faculty of Mechanical Engineering of Silesian University of Technology in 2015.

\section{REFERENCES}

${ }^{1}$ B. Masek, C. Stadler, H. Jirkova, P. Feuser, M. Selig, Transformation-induced plasticity in steel for hot stamping, Mater. Tehnol., 48 (2014), 555-557

${ }^{2}$ A. Kokosza, J. Pacyna, Formation of medium carbon TRIP steel microstructure during annealing in the intercritical temperature range, Archives of Metallurgy and Materials, 59 (2014), 1017-1022

${ }^{3} \mathrm{~S}$. Wiewiorowska, Analysis of the influence of drawing process parameters on the mechanical properties of TRIP-structure steel wires, Archives of Metallurgy and Materials, 58 (2013), 573-576

${ }^{4}$ A. Grajcar, M. Opiela G. Fojt-Dymara, The influence of hot-working conditions on a structure of high-manganese steel, Archives of Civil and Mechanical Engineering, 9 (2009), 49-58

${ }^{5}$ S. Lasek, E. Mazancova, Influence of thermal treatment on structure and corrosion properties of high manganese triplex steels, Metalurgija, 52 (2013), 441-444

${ }^{6}$ L. A. Dobrzański, A. Grajcar, W. Borek, Microstructure evolution of C-Mn-Si-Al-Nb high-manganese steel during the thermomechanical processing, Materials Science Forum, 638-642 (2010), 3224-3229, doi:10.4028/MSF.638-642.3224

${ }^{7}$ M. Jabłońska, G. Niewielski, R. Kawalla, High-manganese TWIP steel - technological plasticity and selected properties, Solid State Phenomena, 212 (2014), 87-90, doi:10.4028/SSP.212.87

${ }^{8}$ A. Grajcar, R. Kuziak, Dynamic recrystallization behavior and softening kinetics in 3Mn-1.5 Al TRIP steels, Advanced Materials Research, 314-316 (2011), 119-122, doi:10.4028/AMR.314-316.119

${ }^{9}$ M.S. Weglowski, S. Stano, G. Michta, W. Osuch, Structural characterization of Nd:YAG laser welded joint of dual phase steel, Archives of Metallurgy and Materials, 55 (2010), 211-220

${ }^{10}$ F. Nikoosohbat, S. Kheirandish, M. Goodarzi, M. Pouranvari, Effect of tempering on the microstructure and mechanical properties of resistance-spot-welded DP980 dual-phase steel, Mater. Tehnol., 49 (2015), 133-138

${ }^{11}$ M. Amirthalingam, M. J. M. Hermans, I. M. Richardson, Microstructural development during welding of silicon- and aluminum-based transformation-induced plasticity steels - inclusion and elemental partitioning analysis, Metallurgical and Materials Transactions A, 40 (2009), 901-909, doi:10.1007/s11661-008-9761-5

${ }^{12}$ A. Grajcar M. Różański M. Kamińska B. Grzegorczyk, Study on non-metallic inclusions in laser-welded TRIP-aided Nb-microalloyed steel, Archives of Metallurgy and Materials, 59 (2014), 1163-1169, doi:10.2478/amm-2014-0203

${ }^{13} \mathrm{~J}$. Maciejewski, The effects of sulfide inclusions on mechanical properties and failures of steel components, Journal of Failure Analysis and Prevention, 15 (2015), 169-178, doi:10.1007/s11668-015-9940-9

${ }^{14}$ I.J. Park, S.M. Lee, M. Kang, S. Lee, Y.K. Lee, Pitting corrosion behavior in advanced high strength steels, Journal of Alloys and Compounds, 619 (2015), 205-210, doi:10.1016/j.jallcom.2014. 08.243

${ }^{15}$ J. Górka, Weldability of thermomechanically treated steels having a high yield point, Archives of Metallurgy and Materials, 60 (2015), 469-475, doi:10.1515/amm-2015-0076

${ }^{16}$ R. Celin, J. Bernetic, D.A. Skobir Balantic, Welding of the steel grade S890QL, Mater. Tehnol., 48 (2014), 931-935

${ }^{17}$ A. Lisiecki, Welding of thermomechanically rolled fine-grain steel by different types of lasers, Archives of Metallurgy and Materials, 59 (2014), 1625-1631, doi:10.2478/amm-2014-0276 